УДК 352.071.55:339.138](043.2)

DOI: 10.34132/pard2021.13.04

\title{
БРЕНДИНГ ТЕРИТОРІЇ ГРОМАДИ - МЕХАНІЗМ ФОРМУВАННЯ ЛОКАЛЬНОЇ ІДЕНТИЧНОСТІ ТА ФАКТОР КОНКУРЕНТОСПРОМОЖНОСТІ
}

Свтушенко О. Н., д-р політ. наук, професор, Інститут державного управління, Чорноморський національний університет імені Петра Могили, м. Миколаїв, Україна.

Суслов М. M., магістр публічного управління та адміністрування, докторант $\mathrm{PhD}$, Інститут державного управління, Чорноморський національний університет імені Петра Могили, м. Миколаїв, Україна.

Bepбa C.M., ст. викладач, Інститут державного управління, Чорноморський національний університет імені Петра Могили, м. Миколаїв, Україна.

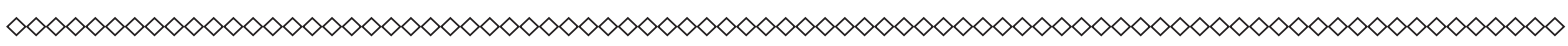

У статті розглянутий взаємозв'язок між брендингом території у новостворених об'єднаних територіальних громадах (далі ОТГ) та формуванням локальної ідентичності ОТГ як фактора ї̈ конкурентоспроможності.

Надано визначення понять «бренд» та «брендинг», які пропонуються вітчизняною на зарубіжною науковими школами. Доведено, щьо брендинг території ОТГ-це своєрідна стратегія, спрямована на поліпшення іміджу адміністративно-територіальної одиниці для залучення інвесторів, туристів, бізнесменів. Виділено функиії бренду території ОТГ, які стосуються користувача (ідентифікаціï, персоналізації, гарантії, спрощення рішення та задоволення) $i$ зазначено, щуо ефективне просування бренду залежить від інвестицій вкладених в його первісне просування, насамперед, в інформативну рекламу.

Доведено, щуо локальна ідентичність, як місие проживання, територія, щуо має певні відмінності, характеристики і стає брендом, 
а брендинг - механізм спрямований на згуртування локальних співтовариств, що проживають на території ОТГ, формування уявлення про власну ідентичність до иієї території. У статті бренди окремих територій громад визначені, як локальні бренди, щз характеризують ментальність місиевого населення, його наближеність до культурних та історичних традицій, щзо обумовлене природногеографічними, економічними, історичними та соціально-культурними факторами. Зроблено акцент на використанні логотипу та інших візуальних атрибутів бренду громади для посилення локальної ідентичності, тобто самоототожнення індивідів з місцевим співтовариством, заснованої на культурно-психологічній єдності населення. Бренд території ОТГ є інструментом реалізації стратегії розвитку громади, тому щзо акумулює інтереси ї̈ населення, інвесторів, бізнесу, влади, i, таким чином, виступає фактором конкурентоспроможності.

Ключові слова: територї̈, ОТГ, бренд, брендинг, локальна ідентичність, брендбук, конкурентоспроможність.

Постановка проблеми у загальному вигляді. Реформа децентралізації викликала необхідність переходу до нової системи публічного управління, де місцеве самоврядування на рівні об'єднаних територіальних громад (далі ОТГ) стає ключовим елементом української державності й важливим фактором соціально-економічного розвитку територій громад. Усе це спонукує дослідників приділяти особливу увагу формуванню територіальних брендів, що сприяють посиленню локальної ідентичності ОТГ і, як наслідок цього процесу, спостерігається підвищення привабливості ОТГ в очах значної кількості людей.

Створення бренду території ОТГ - затребувана послуга, яку потребують зацікавлені сторони (наприклад, інвестори, державні органи, населення громади, органи місцевого самоврядування, місцеві компанії й ін.) для того, щоб забезпечити соціальну стабільність, залучити інвестиції. Сприятливий бренд території громади, присутність iї в інформаційному просторі, допоможе залучити потен- 
ційних інвесторів, які допоможуть розвити економічний потенціал ОТГ, зміцнити конкурентні позиції, створити додаткові переваги території ОТГ в економічному просторі; це важливий елемент, що забезпечує соціальну стабільність через підвищення рівня самооцінки жителів території. Тому варто націлювати плани з розвитку ОТГ, робити акцент не тільки на економічній стороні життя, але й на людському факторі. Щодо цього бренд ОТГ виглядає виграшніше, ніж бренд товару тому, що в ОТГ обов'язково $є$ присутньою своя неповторна історія, а товару потрібно придумувати «легенду».

Актуальність вивчення брендингу території пов'язано: по-перше, $з$ тим, що в сучасних умовах бренд є невід'ємним елементом прискореного розвитку території громад, а тому його розробка й створення повинні сприяти подальшому посиленню локальної ідентичності населення місцевого співтовариства, через активізацію його в житті громади. По суті, брендинг ОТГ є інструментом підвищення привабливості території громади, механізмом соціальної взаємодії і механізмом відтворення суспільного порядку в громаді, зокрема, шляхом формування локальної ідентичності, як простору комунікацій у межах ОТГ. По-друге, члени ОТГ зіштовхуються 3 проблемою збереження цілісності ОТГ й успішною адаптацією до стрімко мінливих соціальних умов, що вимагає соціального включення представників громади до ресурсів ОТГ та можливості розпоряджатися ними. По-третє, формування локальної ідентичності ОТГ вимагає інтегрування індивідів і територіальних спільнот, що мають свою локальну ідентичність, свою історичну, культурну, соціальну, економічну специфіку у нові суспільні взаємовідносини, що формуються в ОТГ. По-четверте, запровадження брендингу території ОТГ призводить до формування позитивного іміджу громади, що, в свою чергу, сприяє формуванню лояльності груповим цілям, нормам та цінностям, а також залученню інвестицій, розвитку туризму, розширенню ринків збуту продукції й, як наслідок, поліпшенню інфраструктури території громади, залученню трудових ресурсів і багато чого іншого.

Таким чином, просування бренду території ОТГ - це не тільки позиціювання ОТГ для орієнтації бізнесменів, підприємців, інвес- 
торів, туристів, покупців товарів і послуг, що надаються, але механізм формування локальної ідентичності, що вимагає всебічного наукового аналізу вказаної проблеми.

Аналіз останніх досліджень і публікацій. Теоретичні й практичні аспекти створення бренду, брендингу території досліджували представники вітчизняної (О. Біловодська, К. Богун, Н. Гайдабрус, О. Свтушенко, М. Карпищенко, Я. Котенко, Т. Нагорняк, І. Павлова, О. Соскін, А. Ткачук, Ю. Шатава,), російської (В. Амелін, Я. Беван, Е. Веттер, Т. Виноградова, Л. Кузнецова, О. Кусраєва, Е. Морозова, I. Самошкіна, Я. Семілетова, О. Шеметова, Е. Улько, С. Ясько) та західноєвропейської (С. Анхольт, К. Асплунд, Г. Брейквелл, К. Дінні, Ф. Котлер, Ж.-Л. Нансі, А. Нойманн, Г. Раагмаа, І. Рейн, 3. Рікель, В. Свамінатан, Д. Хайдер) наукових шкіл. Класифікацію теоретичних досліджень брендингу територій умовно можна поділити на дослідження: по-перше, пов'язані з виявленням сутнісних характеристик бренду; по-друге, роботи, що присвячені обгрунтуванню методологічних принципів і концепцій позиціювання території громади, тобто - це маркетинг території; по-третє, дослідження присвячені виробленню технологічних алгоритмів побудови просування й управління брендом території; по-четверте, дослідження, що описують моделі і методи оцінки потенціалу й цінності бренду.

У навчальному посібнику «Ресурсне забезпечення об'єднаної територіальної громади та їі маркетинг», авторами якого $є$ В. Куйбіда, А. Ткачук, В. Юзефович, викладені теоретичні та практичні аспекти формування ресурсного потенціалу ОТГ, а саме надане визначення брендингу території ОТГ, як «процес формування й управління брендом; що включає в себе його створення, посилення, просування, оновлення, можливе репозиціювання, ребрединг» [14, c. 85].

Теоретико-методичні засади створення бренда міста відображені у статті українських дослідників О. Біловодської та Н. Гайдабрус [2], К. Богуна [3, с. 40-45]; Ю. Шатава та М. Карпищенко займаються вивченням питань брендування території; пропонують механізм розробки та просування бренду території згідно зі стратегією розвитку регіону [26, с. 324-329]; О. Свтушенко і I. Присяжненко 
характеризують концепт «брендинг держави» [10, с. 33-37]; I. Павлова досліджує стратегію брендингу ОТГ Південного регіону [20, с. 199-203]. Т. Нагорняк зазначає, що «будь-яка територія може стати брендом за умов виваженої стратегії брендингу і ребрендингу (своєчасної корекції бренду, що обумовлена ринковим попитом)» [18, с. 54]. За переконанням О. Соскіна, бренд території - це «премія» у вигляді соціальної стабільності, припливу інвестицій, збільшення туристичних потоків і т. д. Це гарантоване майбутнє міста та його соціуму [5, с. 17].

Дослідниця О. Кусраєва визначає основні функції, які здійснюються брендингом з моменту його виділення в якості окремого наукового напрямку по теперішній час та представляє функціонал, що сформувався в брендингу в результаті «виникнення нових інформаційних і комунікаційних технологій» [15, с. 69-91].

Надзвичайну цінність для нашого дослідження становлять доробки С. Анхольта $[1 ; 29 ; 30]$, який ввів у науковий обіг систему оцінки національного бренда під назвою «Anholt Ipsos Nation Brand Index» за такими напрямками розвитку: людина, уряд, інвестиції, туризм, експорт, культурна спадщина, імміграційні процеси, а також термін «брендинг міст», що привело до актуалізації проблеми брендингу територій. В його концепції конкурентної ідентичності запропоновано шість елементів бренду території: туризм, населення, політика, культура, бізнес (інвестиціі) і експортні бренди.

Ф. Котлер, К. Асплунд, І. Рейн, Д. Хайдер першими запропонували концепцію про те, що у сучасному світі громадяни стали споживачами, а території - товарами і окреслили напрямки розвитку територій (місто, регіон, країна) [13]. Ф. Котлер, професор Вищої школи менеджменту Дж. Л.Келлога, наводить аргументи важливості маркетингу в лобіюванні та розвитку територій, зазначаючи, що «... в мінливому середовищі і такому, що висуває все нові труднощі кожній території потрібен стратегічний маркетинговий план, щоб отримати користь з нової конфігурації. Стратегічне ринкове планування - це не одноразова спроба впоратися з кризою або фінансовою проблемою, а безперервний, довгостроковий процес, необхідний для зустрічі із світовим ринком, який постійно розви- 
вається і пристосування до нього. Території, які твердо керуються загальним маркетинговим планом, зможуть розробити опорну модель, гнучку i, яка дозволяє уникнути скоростиглих і непродуманих рішень» [13, с.10].

В. Свамінатан у своїй статті приходить до висновку, у наш час істотно розширився і інструментарій сучасного брендингу, надавши, таким чином, нові можливості для взаємодії зі споживачами. Інтернет дає змогу створити і транслювати відео, користуватися інтерактивними онлайн-іграми, інтерактивним телебаченням, мобільними додатками, соціальними мережами, блогами, форумами, QR-кодами та ін. [37, с.33-38].

У той же час треба відмітити, що формування спроможних та самодостатніх ОТГ в Україні передбачає, не тільки ресурсне забезпечення ОТГ, але й формування нових підходів до розуміння ролі брендингу території ОТГ у формуванні локальної ідентичності територіальної громади (самоототожнення жителів з територією громади - «малою батьківщиною»), яка спрямована на формування у жителів самосвідомості, місцевого патріотизму, громадськості, місцевих ініціатив. Саме локальна ідентичність, носієм, якої є індивід - член співтовариства ОТГ, напряму пов'язана з проблемою активізації мешканців ОТГ, їх максимального залучення не лише до громадської участі, але й до формування активної життєвої позиції у населення ОТГ, зокрема у соціально-економічному розвитку громади. Але публікацій які б давали відповідь на це питання не існує.

Формулювання цілей статті (постановка завдання). Головною метою дослідження є виявлення взаємозв'язку між брендингом території у новостворених об'єднаних територіальних громадах та формуванням локальної ідентичності ОТГ та фактора іiї конкурентоспроможності, як ідентифікації людини з місцевим співтовариством, почуття причетності до подій, що відбуваються на території безпосереднього проживання.

Виклад основного матеріалу дослідження. На сучасному етапі в умовах децентралізації, формування бренду території ОТГ є поєднанням враження, яке він здійснює на споживачів, що дозволяє покращити привабливість території, а також створити умови для 
залучення всіляких цільових груп (інвесторів, туристів, жителів, працівників) у процес розвитку громади, через розуміння потреб та інтересів іiі мешканців. Зрозуміло, що брендування території - це довгостроковий, комплексний процес, який позитивно впливає на розвиток ОТГ при якому потрібно враховувати сукупність різних факторів, зокрема зацікавлених у цьому процесі сторін. Саме в бренді закріплюються ідентичність і репутація території громади, регіону й країни.

У сучасних умовах бренд $є$ найбільш ефективним інструментом у конкурентній боротьбі громади за ресурси, у розбудові необхідної соціальної та культурної інфраструктури ОТГ, ідентифікації людини (індивіда) з місцевим співтовариством. Одним 3 підтверджень цього твердження є проведене соціологічне дослідження, що дає уявлення про локальну ідентичність. Так, більшість респондентів (57\%), на питання з ким вони ідентифікують себе, дали відповідь, що з мешканцями своєї ОТГ (табл. 1).

Таблиця 1.

«3 ким ви себе ідентифікуєте (ототожнюєте) ?»

\begin{tabular}{|l|c|}
\hline Питання & Відповіді (\%) \\
\hline Громадянином України & 32.4 \\
\hline $\begin{array}{l}\text { Мешканцем об’єднаної } \\
\text { територіальної громади }\end{array}$ & 57 \\
\hline Мешканцем області & 7.5 \\
\hline Мешканцем району & 3.1 \\
\hline
\end{tabular}

Отже, поняття «локальна ідентичність» характеризує, що члени громади сприймають себе, як представники ОТГ, яка базується на єдності території проживання, історично-культурному, соціальному досвіді, ціннісних орієнтаціях та способу життя. Друге місце у рейтингу серед чотирьох видів ідентичностей є громадянство України.

Брендинг території - це ефект загального й позитивного сприйняття території, заснований на символічному капіталі місця, що 
«виникає в результаті репрезентації міської ідентичності в іміджі території» [6, с. 81].

У зв'язку з тим, що локальна ідентичність ОТГ характеризує місце людини в соціумі місцевого співтовариства потрібно визначитись з ії структурою. Сдиної точки зору в цьому питанні не має. Ототожнюючи локальну ідентичність з територіальною, різні вчені і1і структуру розкривають через різні елементи. Наприклад, Г. Бреквел запропонував модель, що опирається на чотири компоненти: безперервність, самооцінка, самоефективність і розходження [31, с. 12-30]. На думку I. Самошкіної локальна територіальна ідентичність визначається важливістю місця проживання для індивіда й формується через його позитивне ставлення до нього, внаслідок задоволеності ним [24, с. 67]. Дійсно місце проживання грає важливу роль й воно відбивається в ідентичності, як формі організації відносин між індивідом і співтовариством ОТГ, тобто людьми, які оточують індивіда, що виражається у формуванні соціальних зв'язків, особливостях поведінці, спілкуванні. Локальна ідентичність не є постійною, вона змінюється під впливом змін, що відбуваються в житті людини. Ще німецький політолог А. Нойманн писав: «... ідентичність - це не даність, а відношення, що постійно формується й реформується в рамках певного дискурсу» [34, с. 349]. Тому що локальна ідентичність ОТГ - це «комплекс заходів, що об'єднують громаду» [9, с. 414], що дозволяє людині самосприймати себе членом співтовариства. У той же час бренд ОТГ лише один з компонентів, що у певній ситуації виступає на перший план, а тому грає важливу роль у її формуванні.

Отже, брендинг території ОТГ є способом, механізмом, що об'єднує індивідів. Він дає індивідам можливість репрезентувати себе як співтовариство i, як зазначає Ж.-Л. Нансі «саме співтовариство являє собою цей простір» $[19$, с. 180].

Також брендинг території ОТГ характеризує стан та тенденції розвитку території, наявних в ній ресурсів і активів, підвищує іiі привабливість та престиж, що необхідно для забезпечення якісної конкуренції ОТГ за інвестиційні фінансові ресурси, а тому є фактором конкурентоспроможності ОТГ, що дає громаді додаткові переваги території в економічному просторі. 
По суті брендинг території ОТГ є перформативним актом вираження локальної ідентичності. Повідомленням (дією), препозитивна складова якої не може бути оцінена в межах категорій істинності / неістинності. Це дія, що зроблена в певний час, у певному місці, у певних обставинах. «Майже будь-яке наше судження також має ідентичностний зміст і реалізує певну політику ідентичності, що означає примикання до одного співтовариства або групи й протиставлення другому; воно виражає нашу самість, «Я», тобто реалізує якийсь аспект нашої потреби перебування в конкретних обставинах» [25, с.48]. Як наголошують автори монографії «Свої й чужі. Метаморфози ідентичності на сході й заході Свропи»: «Зберігати ідентичність - це значить здійснювати зусилля по іiї відтворенню, протиставляючи загрозливим змінам, постійну роботу втримання й збереження собі-тотожності» [25, с.48].

Отже, власний унікальний бренд демонструє потенціал ОТГ, за його допомогою формуються та розповсюджуються бажані уявлення про громаду із іiі природними, історичними, культурними, духовними особливостями, соціально-економічними інтересами мешканців, рівнем розвитку соціальної та виробничої інфраструктури [17, c. 150].

Відзначимо, що перші проекти комплексного регіонального й державного брендингу стали проявлятися ще в другій половині XX сторіччя на Заході, але це були однотипні й дрібномасштабні дослідження, що спеціалізуються на якомусь одному аспекті, наприклад, туризмі. Культура бренду ввійшла в сферу міського маркетингу двома бізнес-каналами: виїзний туризм і експорт місцевих товарів і послуг. Імовірно, туристичні компанії, перші, хто стали вживати термін «бренд міста», а пов'язано це $з$ тим, що туризм - це бізнес, $\mathrm{i}$ туристичний маркетинг ближче інших до корпоративного середовища, у якому народилося поняття бренду [28, с. 140-142].

Термін «бренд» (англ. brand) brand-name (значення brand: клеймо, тавро) з'явився на Дикому Заході, для ідентифікації приналежності худоби. Зараз термін «бренд» схожий з термінами «товарний знак» або «торговельна марка», те, що відрізняє компанію від конкурентів. Бренд - це сукупність уявлень, асоціацій, емоцій і цінностей 
у головах потенційних споживачів. Його мета - помножити цінність товару/послуги для потенційного споживача. По суті, він «впливає на індивідуальну, групову та масову свідомість, однак при цьому в кожної людини він формується та розвивається по-своєму, незважаючи на певну одноманітність вихідного положення щодо свого сприйняття» [10, с. 34].

На думку С. Анхольта, який ввів в обіг термін «брендинг міста», бренд території може містити в собі офіційну символіку (прапор, герб, гімн), а також фірмовий стиль (логотип і т.д.) [1, с. 34]. Але незважаючи на це, до сього часу не існує єдино вірного визначення поняття «територіальний брендинг».

Розробка концепції бренду - це формування його ідеї, що спрямована на споживача. К. Дінні наголошує, що «комунікаційна іміджева стратегія регіону містить у собі креативну концепцію й концепцію просування» [7, с. 27]. У маркетингу бренд визначається як знак, символ, що дозволяє ідентифікувати товари або послуги. Успішний бренд формується на основі наступних показників: гарна репутація, імідж, асоціації, що виникають у свідомості людей, коли вони чують ту або іншу назву, або бачать якісь атрибути, не тривіальна історія створення й розвитку компанії й ін. Ефективне просування бренду залежить від інвестицій вкладених в його первісне просування, насамперед, в інформативну рекламу. Так компанія-власник має можливість довгі роки експлуатувати імідж бренду, підтримуючи його лише за рахунок незначних витрат, при цьому одержувати з кожної одиниці продукції прибуток за «популярність» бренду.

Об'єднання конкурентних зусиль може бути результатом злиття або поглинання компаній, які працюють в одному секторі або в зовсім різних сферах. У таких випадках створюються до-брендингові проекти. До-Брендинг (Co-Branding) - це спільне використання комунікаційних каналів для розвитку ринкової ніші. Вдалий приклад подібного приєднання є бренд "Shure Incorporated" - провідний виробник мікрофонів і аудіо-електроніки, що в 2011 р. ввів у свій склад компанію DIS (Danish Interpretation Systems), яка провадить устаткування для аудіоконференцій. 
Оскільки у сфері державного управління концепти «бренд» i «брендинг» все ще знаходяться в стані активного дискурсу, то можна спостерігати відсутність єдиного підходу до їхньої дефініції (табл. 2).

Таблиця 2.

Значення понять «бренд» та «брендинг»

\begin{tabular}{|c|c|}
\hline $\begin{array}{c}\text { Автори } \\
\text { визначення }\end{array}$ & Дефініція понять «бренд» та «брендинг» \\
\hline С. Анхольт & $\begin{array}{l}\text { «Бренд - це ідентичність продукту (упаковка, } \\
\text { зовнішній вигляд, логотип та ін.); бренд - це культура } \\
\text { організації, що стоїть за брендом; бренд - репутація } \\
\text { продукту чи корпорації, що склалася у свідомості } \\
\text { споживачів» [30]. }\end{array}$ \\
\hline К. Дінні & $\begin{array}{l}\text { «брендинг - інструмент, що дозволяє втримувати } \\
\text { й залучати жителів, відвідувачів і інвесторів». } \\
\text { Територіальний брендинг - це «процес, який } \\
\text { сприяє створенню найреалістичнішого, найбільш } \\
\text { конкурентоспроможного й успішного стратегічного } \\
\text { бачення міста, регіону або країни» }[32, \text { p.106]. }\end{array}$ \\
\hline $\begin{array}{l}\text { О.Н. Свтушенко, } \\
\text { I.О.Присяжненко }\end{array}$ & $\begin{array}{l}\text { «Брендинг - це вид діяльності, спрямований на } \\
\text { створення стійких уявлень у свідомості споживачів } \\
\text { про об’єкт» [10, с. } 34] .\end{array}$ \\
\hline $\begin{array}{l}\text { T. Мойланен } \\
\text { С. Райністо }\end{array}$ & $\begin{array}{l}\text { «Бренд - враження, яке сприймається клієнтом про } \\
\text { товар чи послугу» [33, с. 6] }\end{array}$ \\
\hline $\begin{array}{l}\text { О. А. Біловодська } \\
\text { Н.В.Гайдабрус }\end{array}$ & $\begin{array}{l}\text { «Територіальний брендинг - це найбільш ефективний } \\
\text { інструмент позиціювання регіону, процес побудови, } \\
\text { розвитку та управління брендом, мета якого - } \\
\text { створення сильного і конкурентоспроможного } \\
\text { регіону» }[2, \text { с. } 35-43] .\end{array}$ \\
\hline Я. Котенко & $\begin{array}{l}\text { «Бренд громади - це досить складний продукт, } \\
\text { розробка якого має здійснюватись фаховими } \\
\text { установами із залученням максимальної кількості } \\
\text { активних мешканців громади та подальшим } \\
\text { затвердженням на сесії» }[12, \text { с. } 37] \text {. }\end{array}$ \\
\hline
\end{tabular}

Примітка: складено автором. 
Таким чином, бренд - можна визначити, як комплекс уявлень, асоціацій, емоцій, ціннісних характеристик про територію, продукт або послугу, що робить його унікальним у свідомості споживача. При цьому, бренд, характеризує які-небудь особливості території, якості продукту або характеристики самого виробника продукту. Саме тому бренд території, зокрема ОТГ, є інструментом маркетингової діяльності, що сприяє підвищенню привабливості території для інвесторів, організацій та підприємств - виробників товарів та надавачів різноманітних послуг. Крім того, бренд є складовою іміджевої кампанії, одним із головних факторів успішного позиціювання громади. Брендинг, на відміну від бренду - це вид діяльності, що відповідає за створення, втілення та посилення бренду.

У сучасних умовах формування бренду території ОТГ, тобто брендинг може розглядатися як фактор посилення конкурентоспроможності територіальної громади на ринку товарів та послуг. Отже, бренд території ОТГ по суті - це:

- стереотип, умовний образ (позитивний імідж) території громади, іiі потенціалу сформований у свідомості місцевого населення, а також ймовірних інвесторів та споживачів, тобто - це конкурентний ресурс ОТГ у порівнянні з іншими громадами;

- асоціації і міфи, що укорінені у свідомості населення громади і ототожнюють людину з територією ОТГ й людьми, що проживають на цій території;

- культурний контент (історія, культура, символи, ідеологеми), тобто символічне маркування значимих для ОТГ місць, які акумулюють його історичну, культурну пам'ять;

- товар, що відповідає потребам деяких користувачів і становить для них якусь додаткову цінність, здатну задовольнити певні психічні потреби й спонукати до взаємовідносин з ОТГ;

- нематеріальний актив ОТГ, як економічного суб'єкту;

- певний знак якості, що «повідомляє», що громада відповідає вказаним стандартам.

Під брендом території ОТГ можна представити переваги, які йому дасть відвідування цього місця, розуміти здатність органів місцевого самоврядування (далі ОМС). Під територіальним брен- 
дингом слід розуміти процес формування, розробки й просування територіальних брендингів у свідомості місцевих жителів, туристів, громадськості, і влади з метою створення певних репутаційних переваг відповідної ОТГ. Створення бренду території ОТГ можливо декількома шляхами: 1) через створений уже у свідомості людей образ, позитивний імідж й ін.; 2) через асоціації з територією; створеними на ній товарами й послугами, конкретними людьми й т.п.; 3) через розробку ефективної стратегії ОТГ, що враховує конкурентний потенціал території.

В основі брендингу територій лежать такі цілі: 1) мобілізація зовнішніх і вдосконалення внутрішніх всіх видів ринків; 2) позбавлення від дефіциту різноманітних ресурсів; 3) зростання впізнаваності та популярності території через правильну їі подачу в 3МI; 4) адресне створення позитивної громадської думки про ідентичність території. Сьогодні можна виділити п’ять функцій

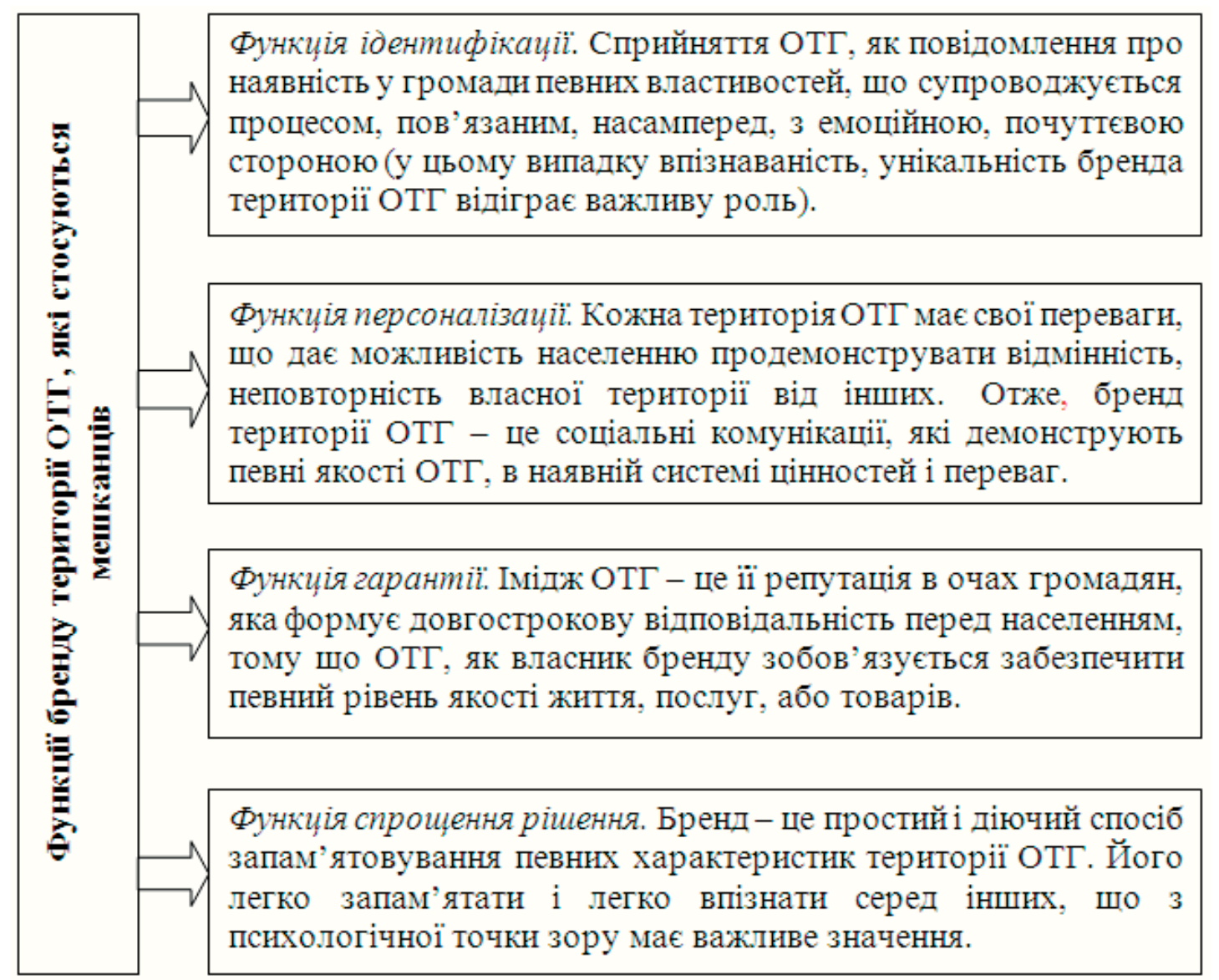

Puc. 1. Функції бренду території ОТГ, які стосуються громадян 
Також можна виділити чотири функції бренду території ОТГ, які стосуються стратегічного значення території об'єднаної громади, як економічного суб'єкта (Рис. 2).

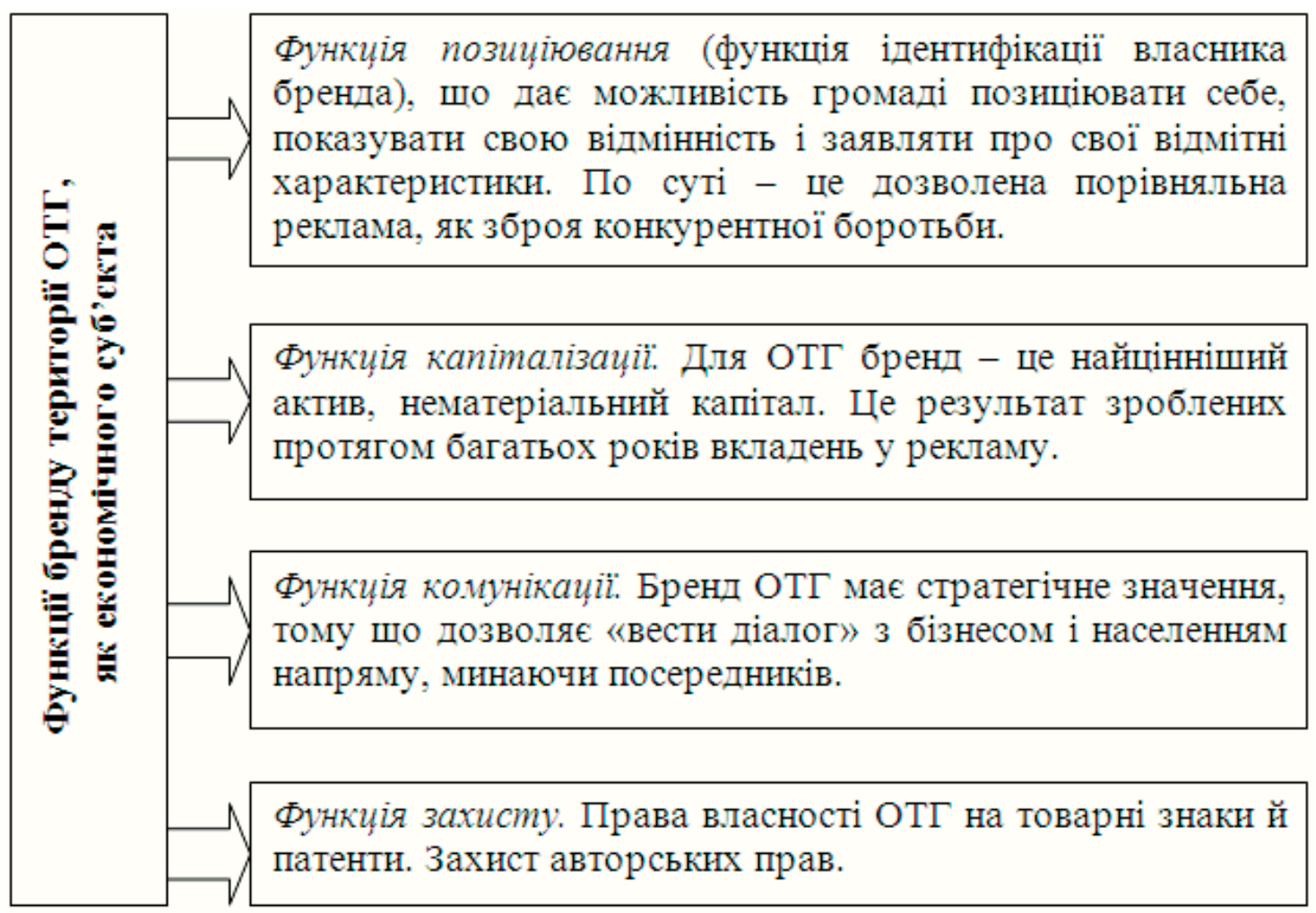

Puc. 2. Функції бренду території ОТГ, як економічного суб’єкта

Таким чином, не можна недооцінювати значну роль бренду ОТГ - це найцінніший стратегічний актив територіальної громади, як економічного суб'єкта. Їм необхідно грамотно управляти, у т.ч. 3 метою залучення потенційних інвесторів, впливаючи на почуттєве сприйняття його не тільки населенням ОТГ, але й іншими громадянами.

Бренд території громади дає ОТГ, як економічному суб'єктові додаткові переваги:

- збільшення прибутку, через підвищення цін або росту обсягів продажів;

- ріст вартості бренду в часі: довговічність бренду дає надприбуток на більш тривалий строк;

- зниження економічних і підприємницьких ризиків, формування конкурентної стійкості території на базі створеного бренду. 
Брендинг території ОТГ невіддільний від процесів, що відбуваються на ii території, підвищення ii привабливості в очах інших сприяє підвищенню iї конкурентоспроможності, тому що бренд $\epsilon$ демонстрацією конкурентних переваг території ОТГ, фактором iï конкурентоспроможності.

У короткостроковому періоді конкурентоспроможність ОТГ цілком залежить від наявності базових порівняльних переваг як потенціалу для розвитку конкурентних переваг. У довгостроковому ж періоді конкурентоспроможність ОТГ визначається здатністю органів влади й ринкових інститутів створювати ефективні механізми для трансформації порівняльних переваг у конкурентні, їхнього розвитку й постійного вдосконалювання. ОМС повинні прагнути до формування такого конкурентного середовища, яка б сприяла підвищенню продуктивності виробництва, стимулюванню вимогливого попиту й т. д. Виділимо наступні параметри, за якими жителі сприймають «території» (Рис. 3).

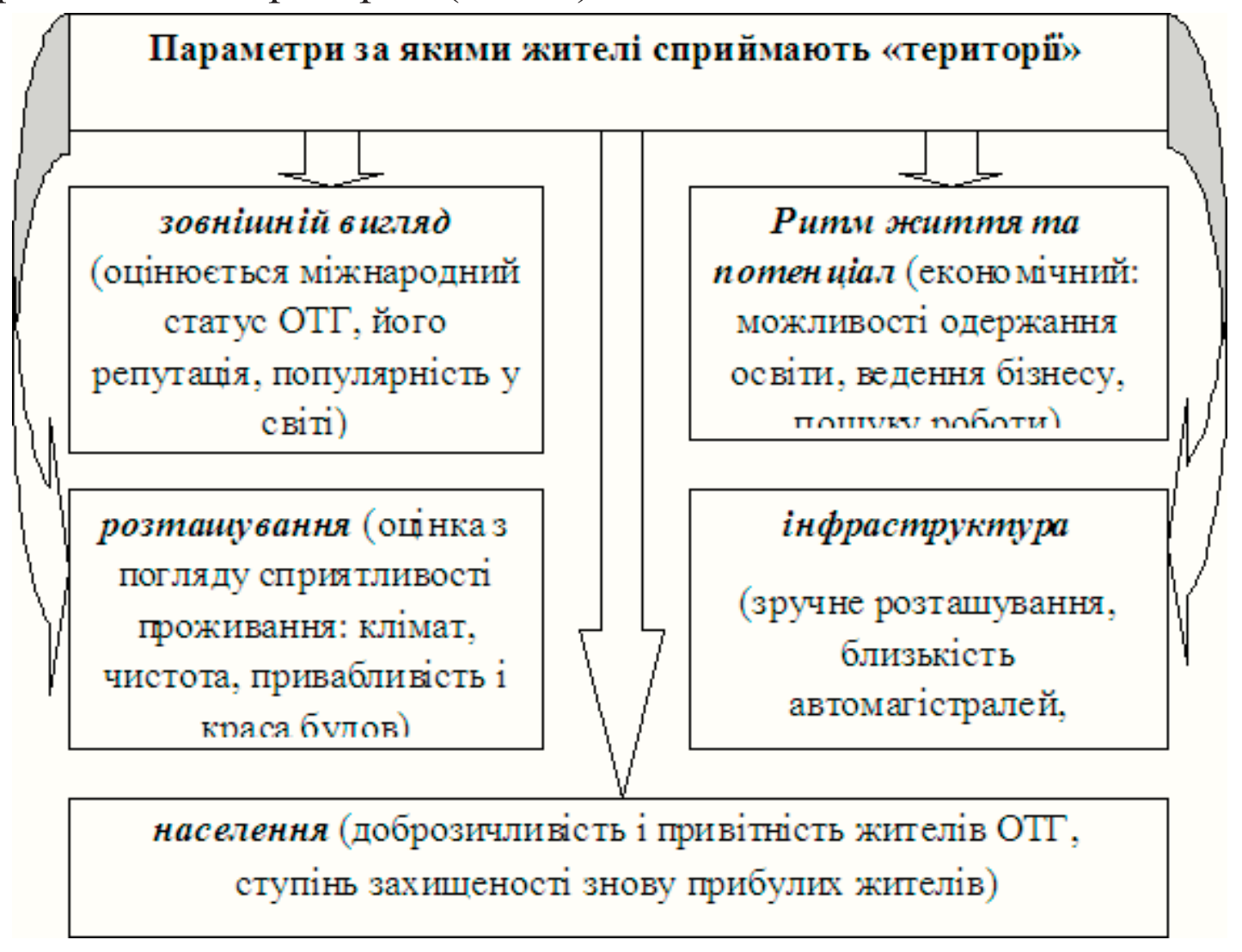

Puc. 3. Параметри за якими жителі сприймають «території» 
Свідомість бренду території ОТГ є синонім терміну локальна ідентичність, що розглядається, 3. Рікелєм як «сприйняття жителями даної просторової одиниці іiї територіальних меж» [36].

Основні групи цільової аудиторії в територіальному брендингу та маркетингу: інвестори - шукачі можливостей; підприємці - шукачі робочої сили та нових бізнес-ніш; партнери - шукачі взаємовигідної співпраці; місцеві жителі - шукачі кращого життя; туристи - шукачі нових вражень (Рис. 4).

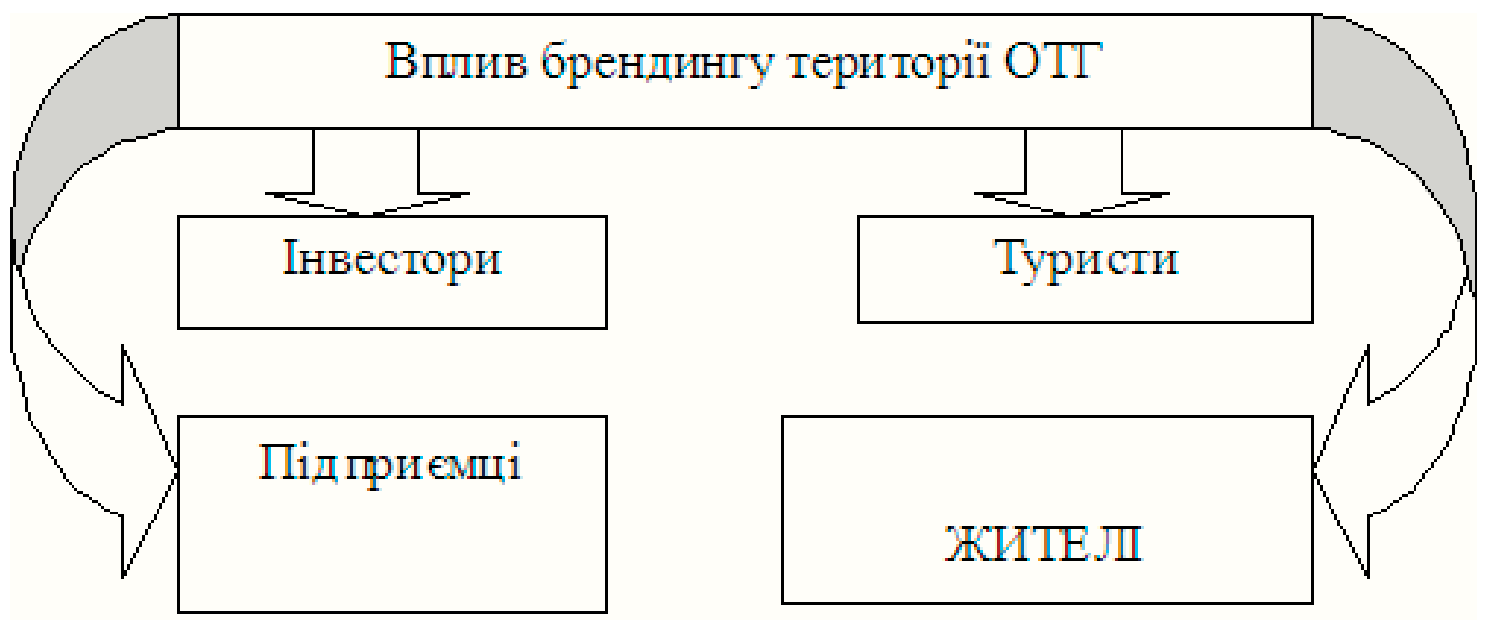

Puc. 4. Вплив брендингу території ОТГ.

Розроблено на основі $[5 ; 7 ; 18]$

Територіальний брендинг практично неможливий без залучення місцевої влади. Остання залучає до цього процесу ще й зацікавлених активних громадян і колективно розробляє успішний план щодо розвитку бренду території.

Безумовно, головне при просуванні бренду ОТГ або регіону це акцентування унікальності. Для успіху повинні бути враховані чотири ключових параметри $[27 ; 8]: 1)$ унікальність; 2) ідеологія, що конвертує унікальність в історію; 3) обгрунтованість факторів формування очікування і його виправданість; 4) оптимальна архітектура.

Повертаючись до бренду ОТГ, варто сказати, що Миколаївська область має величезний потенціал для конкурентної боротьби, і для ефективного розвитку області варто створити унікальний бренд, що 
буде відображати неповторний образ. Підвищення інвестиційного потенціалу, залучення інвестицій в економіку області, створення комфортних умов для бізнесу, активізація в'їзного туризму - все це стратегічні цілі області, тому бренд повинен містити в собі якнайбільше інформації про нашу область. Серед концепцій бренду можна розглянути наступні варіанти: ОТГ - територія інновацій і високих технологій, ОТГ - центр розвитку малих територій (сіл і селищ).

Якщо звернутися до практики просування бренду території, то варто розглянути логотипи та брендбуки певних громад, які як i інші візуальні образи використовуються для позиціювання ОТГ та формування іiі ідентичності.

Так логотип та брендбук (документ інформація про бренд) м. Миколаєва, розроблений дизайнерською студією «Брендарі» (ІваноФранківськ), являє собою літеру «М» складену із двох повних повітря вітрил над хвилями, зверху майорить прапор, що символізує рух вперед та розвиток міста. Під знаком розташований блок з назвою та гаслом міста [16]. Слоган «Місто на хвилі» характеризує географічне положення Миколаєва «на воді» й означає, що місто не стоїть на місці, розвивається й рухається в майбутнє. Основним кольором бренду є синій - колір води, що оточує місто. Але є варіант бренду, де присутні рожеві лінії - колір заходів і сходів сонця, які в Миколаєві неповторні (Рис. 5). 24 грудня 2020 року, міською радою Миколаєва даний бренд та брендбук затверджений як офіційний туристичний логотип міста [4].

Створення бренду Баштанської міської ОТГ - це комплекс заходів (брендинг) і розробка «брендбука - документа, у якому була закріплена інформація про бренд: місія і філософія ОТГ, правила роботи з логотипом, шаблони верстки всіх необхідних носіїв фірмового стилю» [23]. В основу логотипу Баштанської громади, розробленого Українським кризовим медіа-центром покладено елемент роботи Григорія Довженка, символ, що є стилізацією птаха сокола, що летить над степовими балками (Рис. 6). Впровадження бренду є результатом роботи робочої групи, депутатів та електронних консультацій місцевої влади з громадськістю. Саме громадськість 
через електронне голосування із запропонованих трьох зразків обрала наступний [22], тому що він пов'язаний з історичними й культурними традиціями території й місцевого населення (Рис. 5).

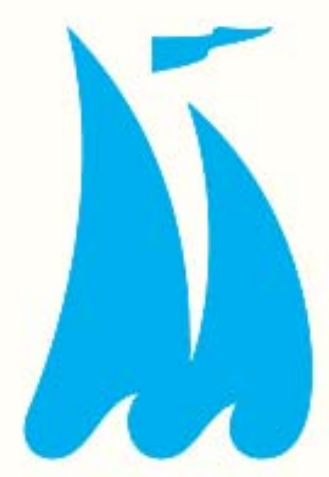

\section{Миколаїв}

Місто нахвилі

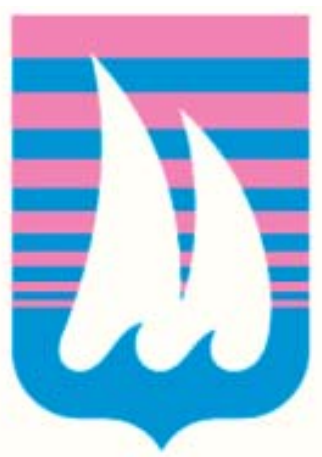

\section{Миколаїв}

місто на хвилі

Puc. 5. Бренд міста Миколаєва.
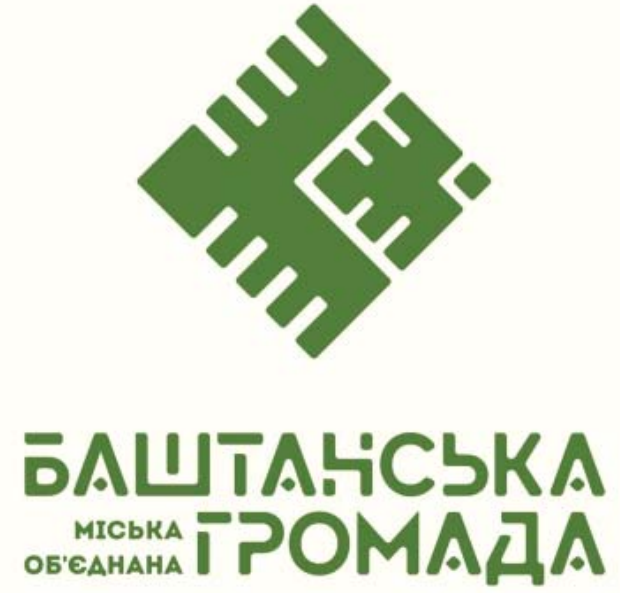

Puc. 6. Логотип Баштанської міської ОТГ.

На наш погляд бренд міста Миколаєва й бренд Баштанської міської ОТГ використовує емоційні зв'язки місцевого населення 3 територією, іiі культурою, традиціями. Можна погодитись 3 Г. Раагмаа, що їх основою є локальна ідентичність територіальної громади, тобто ототожнення себе з соціальною системою певного регіону, з його людьми, культурою, традиціями, ландшафтом тощо [35, c. 57]. 
Отже, бренди окремих територій громад можна визначити, як локальні бренди, що характеризують ментальність місцевого населення, його наближеність до культурних та історичних традицій, що обумовлене природно-географічними, економічними, історичними та соціально-культурними факторами.

Так метою брендингу Миколаєва $є$ формування позитивного іміджу міста, збільшення туристичного потоку, підвищення конкурентоздатності міста в галузі туризму та іiі перетворення у сучасну галузь економіки. Прийнята Миколаївської міською радою «Програма розвитку туристичної галузі міста Миколаєва до 2023 року» [21] враховує туристичний потенціал м. Миколаєва: 347 пам'яток історії та культури (брендові туристичні об'єкти: археологічне городище «Дикий Сад», Миколаївська обласна обсерваторія, Миколаївський зоопарк тощо, фестивальне свято на воді Миколаїв RiverFest, a також транзитні туристичні потоки на Чорноморське узбережжя.

Наприклад, Комунікаційна стратегія Баштанської ОТГ на 20192026 рр. [11] передбачає формування туристично-привабливого образу громади шляхом розробки туристичного бренду ОТГ. Стратегією пропонується оцінити наявний туристичний потенціал Баштанської ОТГ, з огляду на попит та пропозицію (Рис. 6), а також вжити заходи для покращення туристичного позиціювання Баштанської ОТГ та подальших комунікацій з потенційними туристами.

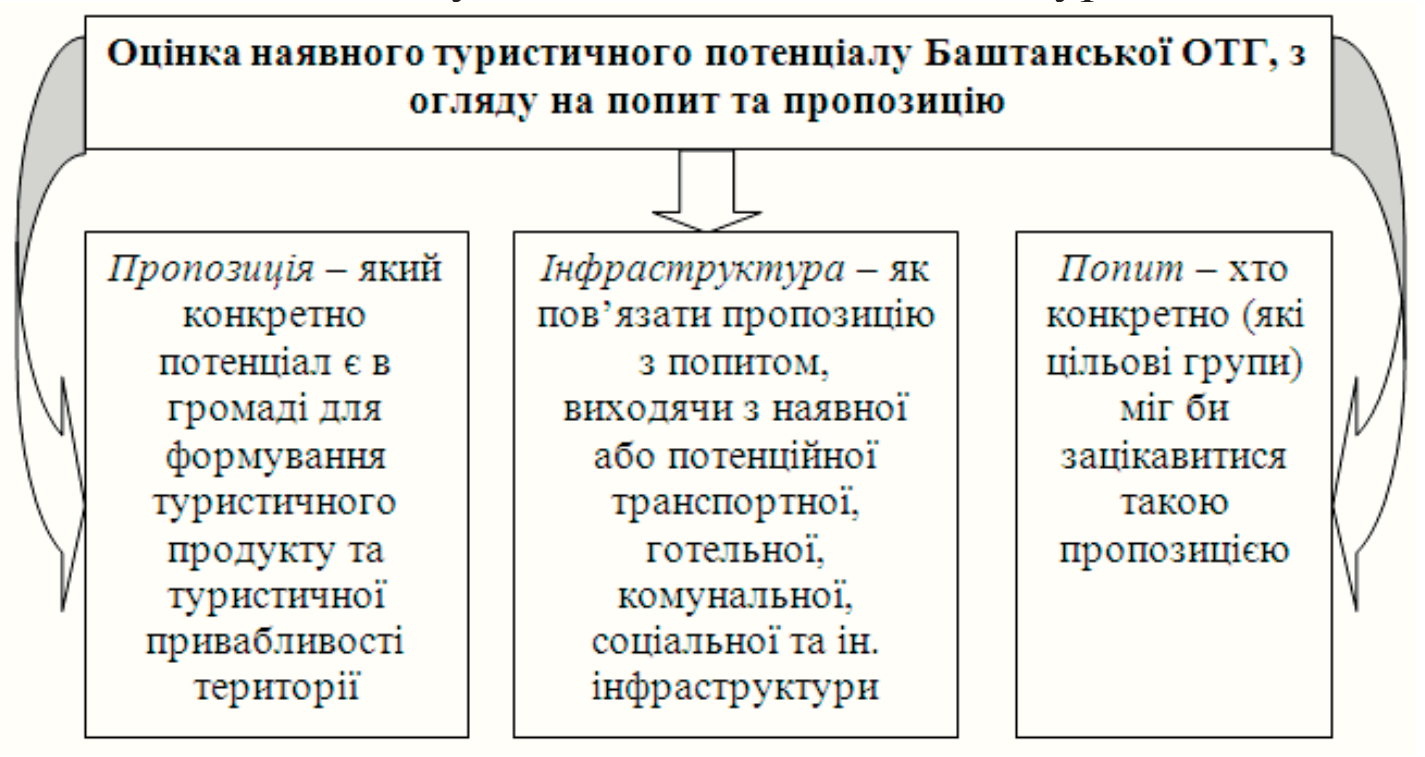

Puc. 6. Оцінка наявного туристичного потенціалу громади 
Перевагами для туристичного позиціювання Баштанської ОТГ 3 огляду на пропозицію, попит та інфраструктуру є такі фактори (табл. 3).

Таблиия 3.

Фактори туристичного позиціювання Баштанської ОТГ

\begin{tabular}{|c|c|c|c|}
\hline Категорія & Фактор & $\begin{array}{c}\text { Перевага } \\
\text { ОТГ }\end{array}$ & $\begin{array}{c}\text { Важливість для тур. } \\
\text { привабливості (від 1 } \\
\text { до 5, у бік зростання) }\end{array}$ \\
\hline Пропозиція & $\begin{array}{c}\text { Історія/видатні } \\
\text { особливості }\end{array}$ & $\begin{array}{c}\text { Батьківщина } \\
\text { М.Аркаса }\end{array}$ & 4 \\
\hline
\end{tabular}

Викликами для туристичного позиціювання Баштанської ОТГ 3 огляду на пропозицію, попит та інфраструктуру є наступні фактори (табл. 4).

Таблиия 4.

Фактори туристичного позиціювання Баштанської ОТГ

\begin{tabular}{|c|c|c|c|}
\hline Категорія & Фактор & $\begin{array}{c}\text { Виклик/ } \\
\text { недолік ОТГ }\end{array}$ & $\begin{array}{c}\text { Важливість для тур. } \\
\text { привабливості (від 1 до } \\
\text { 5, у бік зростання) }\end{array}$ \\
\hline Інфраструктура & $\begin{array}{c}\text { Транспортне } \\
\text { сполучення }\end{array}$ & $\begin{array}{c}\text { Якість доріг } \\
\text { до наступних } \\
\text { об'єктів }\end{array}$ & 4 \\
\hline
\end{tabular}

3 метою посилення конкурентоспроможності Баштанської міської ОТГ Стратегією запропоновано розвивати брендинг території громади, що розкривається у таких аспектах:

- маркетинговій оцінці ринку та конкурентного середовища, 3 метою визначення користувачів, яких можуть зацікавити пропозиції ОТГ;

- формулюванні конкурентних переваг (пропозицій) для конкретних груп споживачів;

- формуванні туристичного бренду Баштанської ОТГ (розробка 
слогану і т.д.) на основі проведеного аналізу із залученням представників громади;

- використанні логотипу та інших візуальних атрибутів бренду громади для посилення локальної ідентичності, тобто самоототожнення індивідів з місцевим співтовариством, заснованої на культурно-психологічній єдності населення;

- розробці маркетингового плану для просування туристичних пропозицій.

Висновки. На сучасному етапі брендинг (процес побудови й просування бренду) - це один з найефективніших інструментів формування й підтримки попиту на споживчому ринку, але й механізм спрямований на згуртування локальних співтовариств, що проживають на території ОТГ, формування уявлення про власну ідентичність до цієї території; метод керування розвитком ОТГ; процес формування конкурентостійкості території. Роль брендингу території ОТГ в сучасному публічному управлінні надзвичайно важлива й не тільки з погляду споживача, виробника товару або послуги, але й території (адміністративно-територіальної одиниці) з багатою історією, природним потенціалом, з розвинутою промисловою й аграрною інфраструктурою, з унікальними соціальними стандартами, спортивними досягненнями й ін. Брендинг території ОТГ спираючись на культурні, трудові традиції й географічне розташування ОТГ характеризує ідентифікацію індивіда з місцевим співтовариством, тобто локальну ідентичність індивідів, що проживають на території ОТГ. Також і сама локальна ідентичність, як місце проживання, територія, що має певні відмінності, характеристики і т.П. стає брендом, а тому конструюється на певних асоціаціях, що й $\epsilon$ предметом дослідження. Тому що вона характеризується усвідомленням індивіда себе як жителя ОТГ, тобто з адміністративно-територіальною одиницею.

Брендинг - це механізм позиціювання ОТГ серед інших ОТГ, конструювання певного образу громади. Питання формування брендингу території ОТГ його використання у внутрішніх й зовнішніх комунікаціях дозволяє залучення таких цільових груп (інвестори, туристи, жителі, працівники). Бренд території ОТГ є інструментом 
реалізації стратегії розвитку громади, тому що акумулює інтереси «стейкхолдерів» - населення, інвесторів, бізнесу, влади, тобто орієнтований на формування передумов, виконуючи найважливішу соціальну функцію - підвищення життєвої мотивації жителів громади, росту їхнього добробуту й благополуччя.

\section{Стаття надійшла до редакції: 19.06.21}

\section{BRANDING OF A TERRITORIAL COMMUNITY AS A MECHANISM FOR FORMING LOCAL IDENTITY AND A FACTOR OF COMPETITIVENESS}

Aleksandr Yevtushenko, Doctor of Political Sciences, Professor, Department of Public Management and Administration, Institute of Public Administration, Petro Mohyla Black Sea National University, Ukraine.

Mykola Suslov, Master of Public Administration, $\mathrm{PhD}$ student, Institute of Public Administration, Petro Mohyla Black Sea National University, Mykolaiv, Ukraine.

Svitlana Verba, Senior Lecturer, Institute of Public Administration, Petro Mohyla Black Sea National University, Mykolaiv, Ukraine.

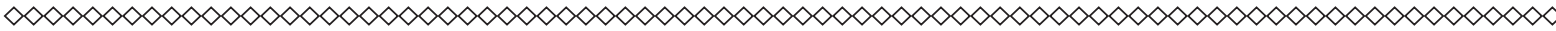

The article examines the relationship between the branding of the territory in the newly united territorial communities (hereinafter UTC) and the formation of the local identity of the UTC as a factor of its competitiveness.

The definition of the concepts "brand" and "branding", which are offered by domestic and foreign scientific schools, is given. It has been proved that branding of the UTC territory is a kind of strategy aimed at improving the image of an administrative-territorial unit in order to attract investors, tourists, businessmen. The functions of the brand of the UTC territory concerning the user (identification, personalization, guarantee, 
simplification of the solution and satisfaction) are highlighted and it is indicated that the effective promotion of the brand depends on the investments made in its initial promotion, first of all, in informative advertising.

It has been proved that local identity, as a place of residence, a territory that has certain differences, characteristics, and becomes a brand, and branding is a mechanism aimed at uniting local communities living on the territory of the UTC, forming an idea of the own identity of this territory. In the article, the brands of individual territories of communities are defined as local brands that characterize the mentality of the local population, its proximity to cultural and historical traditions, which is due to natural-geographical, economic, historical and socio-cultural factors. The emphasis is made on the use of the logo and other visual attributes of the community brand to strengthen local identity, that is, the self-identification of individuals with the local community, based on the cultural and psychological unity of the population. The brand of the UTC territory is a tool for implementing the development strategy of society, since it accumulates the interests of its population, investors, business, government, and, thus, acts as a factor of competitiveness.

Key words: territories, UTC, brand, branding, local identity, brand book, competitiveness.

\section{Received: 19.06.21}

\section{References}

1. Anholt, S. (2010) Brend Amerika: mat vsekh brendov [Brand America: The Mother of All Brands]. Dobraia knyha - Kind book. 232 s. [in Russian].

2. Bilovodska, O. A. (2012) Teoretyko-metodychni zasady stvorennia brenda mista [Theoretical and methodological principles of creating a city brand]. Marketynh i menedzhment innovatsii - Marketing and innovation management. № 1. S. 35-43 [in Ukrainian].

3. Bohun, K. V. (2013) Alhorytm stvorennia i realizatsii prohramy marketynhu i brendynhu mista [Algorithm for creating and implementing 
a marketing and branding program of the city]. Ekonomika $i$ upravleniye Economics and Management. № 2. S. 40-45 [in Ukrainian].

4. Brendbuk «Mykolaiv-misto na khvyli!» [Brandbook "Mykolaiv-city on a wave!']. Retrieved from: https://mkrada.gov.ua/content/brendbuk-mista. html [in Ukrainian].

5. Soskin, O.I. (2011) Brendynh mist: dosvid krain Vyshehradskoi hrupy dlia Ukrainy [City branding: the experience of the Visegrad Group countries for Ukraine]. Kyiv: «Instytut transformatsii suspilstva». 80 s. [in Ukrainian].

6. Vinogradova, T.G.. Semiletova, Ya.I. (2014) Marketing i brending territoriy [Territory marketing and branding] Izvestiya Sankt-Peterburgskogo gosudarstvennogo agrarnogo universiteta - Bulletin of the St. Petersburg State Agrarian University. № 37. S.81-85 [in Russian].

7. Dinni, K. (2013) Brending territoriy. Luchshiye mirovyye praktiki [Territory branding. World best practices] Moscow: Mann. Ivanov i Ferber. 336 s. [in Russian].

8. Dubeykovskiy, V. (2012) Brending gorodov. Nastoyashcheye i budushcheye. Itogi 2012. [City branding. Present and future. Results of 2012] Retrieved from: http://goo.gl/7JZXWf [in Russian].

9. Yevtushenko, O. N. Obiednani terytorialni hromady Mykolaivskoi oblasti v umovakh detsentralizatsii: indykatory efektyvnosti [United territorial communities of Mykolayiv region in the conditions of decentralization: efficiency indicators]. Publichne upravlinnia ta rehionalnyi rozvytok - Public Administration and Regional Development. Mykolaiv, 2020. № 8. S. 396-421 [in Ukrainian].

10. Yevtushenko, O.N., Prysiazhnenko, I.O. (2014) Politolohichnyi vymir kontseptu «brendynh derzhavy» [Political science dimension of the concept of "state branding"] Naukovi pratsi: Naukovo-metodychnyi zhurnal - Scientific and methodical journal "Scientific works". Mykolaiv: Vyd-vo ChDU im. Petra Mohyly, 2014. S. 33-37 [in Ukrainian].

11. Komunikatsiina stratehiia Bashtanskoi OTH na 2019-2026 rr. [Communication strategy of Bashtanska UTC for 2019-2026]. Retrieved from: https://bashtanskaotg.gov.ua/storage/documents/documents/82776ce76363280 2e4ce368f11990782.pdf [in Ukrainian].

12. Kotenko, Ya.V. (2016) Lokalna identychnist yak umova rozvytku obiednanykh terytorialnykh hromad (navchalnyi modul) [Local identity as 
a condition for the development of united territorial communities (training module)]. Kyiv: IKTs «Lehalnyi status», 2016. 48 s. [in Ukrainian].

13. Kotler, F. Asplund, K. Reyn, I. Khayder, D. (2005) Marketing mest: privlecheniye investitsiy. predpriyatiy. zhiteley i turistov v goroda. kommuny. regiony i strany Evropy [Place marketing: attracting investments, businesses, residents and tourists to cities, communes, regions and countries of Europe] Stokgolmskaya shkola ekonomiki v Sankt-Peterburge. 385 s. [in Russian].

14. Kuibida, V. S., Tkachuk, A. F., Yuzefovych, V. V. (2017) Resursne zabezpechennia obiednanoi terytorialnoi hromady ta yii marketynh: navch. posib. [Resource provision of the united territorial community and its marketing: a textbook]. Kyiv [in Ukrainian].

15. Kusrayeva, O. A. (2017) Sovremennaya teoriya brendinga: razdeleniye podkhodov na osnove funktsionalnoy sostavlyayushchey [Modern branding theory: functional separation of approaches] Vestnik Sankt-Peterburgskogo universiteta. Menedzhment 16 (1). S. 69-91 [in Russian].

16. Mykolaiv-misto na khvyli [Mykolaiv-city on a wave]. Retrieved from: https://mkrada.gov.ua/files/Ogoloshenya/\%D0\%91\%D1\%80\%D0\%B5\%D0\% BD\%D0\%B4\%D0\%B1\%D1\%83\%D0\%BA.pdf [in Ukrainian].

17. Morozova, E. V. (2008) Lokalnaya identichnost: formy aktualizatsii i tipy Politeks [Local Identity: Forms of Actualization and Types]. № 4. 299 s. [in Russian].

18. Nagornyak, T.L. (2014) Brending teritoriy u suchasnikh politichnikh praktikakh [Branding of territories in modern political practices]. №3. S. 53-58 [in Ukrainian].

19. Nansi, Zh.-L. (2009) Neproizvodimoye soobshchestvo [Unproductive community]. 208 s. [in Russian].

20. Pavlova, I. O. (2017) Brendynh obiednanykh terytorialnykh hromad Pivdennoho rehionu [Branding of the united territorial communities of the Southern region] Visnyk Odeskoho natsionalnoho universytetu. Seriia: Ekonomika. T. 22, Vyp. 12. S. 199-203. Retrieved from: http://nbuv.gov.ua/UJRN/ Vonu_econ_2017_22_12_45 [in Ukrainian].

21. Pro zatverdzhennia Prohramy rozvytku turystychnoi haluzi mista Mykolaieva do 2023 roku. Rishennia. № 2/17 vid 24 hrudnia 2020 [About the statement of the Program of development of tourist branch of the city of Mykolaiv till 2023. Decision № 2/17 of 24 December 2020]. Retrieved from: https:// mkrada.gov.ua/documents/35171.html [in Ukrainian]. 
22. Rezultaty opytuvannia shchodo zatverdzhennia lohotypu Bashtanskoi obiednanoi terytorialnoi hromady [Results of the survey on the approval of the logo of the Bashtan united territorial community]. Retrieved from: https:// bashtanskaotg.gov.ua/storage/static-pages/documents/8f1 fd9abd6cb99aaf636f e173652e86d.pdf [in Ukrainian].

23. Rozrobka lohotypu - vazhlyvyi etap dlia uspikhu OTH [Logo development is an important step for OTG success] Retrieved from: https://bashtanskaotg.gov.ua/news/rozrobka-logotipu--vazhlivi-etap-dlya-uspihu-otg [in Ukrainian].

24. Samoshkina, I.S. (2008) Territorialnaya identichnost kak sotsialnopsikhologicheskiy fenomen: avtoref. dis. ... kand. psikh. nauk: 19.00.05. [Territorial identity as a socio-psychological phenomenon: author's abstract of the dissertation of the candidate of psychological sciences: 19.00.05.] [in Russian].

25. Amelin, V.V., Ya., Bevan, E., Vetter (2018) Svoi i chuzhiye. Metamorfozy identichnosti na vostoke i zapade Evropy [Ours and others. Metamorphoses of Identity in the East and West of Europe]. 344 s. [in Russian].

26. Shatava, L.Yu. (2012) Mekhanizm razrabotki brenda territorii [Territory brand development mechanism]. Marketing i menedzhment innovatsiy Marketing and innovation management. № 4. S. 324-329 [in Russian].

27. Shemetova, O. Brend - chto eto i zachem on nuzhen [Brand - what is it and why is it needed]. Retrieved from: http://goo.gl/ChWUxt [in Russian].

28. Yasko, S. E. (2012) Neobkhodimost formirovaniya i prodvizheniya brenda goroda [The need for the formation and promotion of the city brand]. Vestnik Chelyabinskogo gosudarstvennogo universiteta - Bulletin of the Chelyabinsk State University. № 3. S. 140-142 [in Russian].

29. Anholt, S. (2009) Places: Identity, Image and Reputation. Palgrave Macmillan. 256 p. [in English].

30. Anholt, S. (2011) "Beyond the Nation Brand: The Role of Image and Identity in International Relations," Exchange: The Journal of Public Diplomacy: Vol. 2: Iss. 1, Article1. Retrieved from: https://surface.syr.edu/exchange/ vol2/iss1/1 [in English].

31. Breakwell, G. M. (2003) Identity. L.: Thousand Oaks; New Delhi. P.12-30 [in English].

32. Dinnie, K. (2004) Place branding: Overview of an emerging literature. Place branding and Public Diplomacy. № 1. P. 106-110 [in English]. 
33. Moilanen, T., Rainisto, S. (2009) How to Brand Nations, Cities and Destinations. New York: Palgrave Macmillan. 202 p. [in English].

34. Neumann, I. B. (1993) Russia as Central Europe's Constituting Other. East European Politics and Societies. Vol. 7. № 2.30. P. 349-369 [in English].

35. Raagmaa, G. (2002) Regional identity in regional development and planning. European Planning Studies. Vol. 10. № 1. P. 55-76 [in English].

36. Rykiel, Z. (2017) Identyfikacja i tożsamość kulturowa w różnych skalach przestrzennych. Opuscula Sociologica. №. 3(21). S. 45-55 [in Polish].

37. Swaminathan, V. (2016.) Branding in the digital era: New directions for research on customer-based brand equity. Academy of Management Science Review 6 (1/2): 33-38. [in English].

\section{Відомості про авторів / Information about the Authors}

Свтушенко Олександр Никифорович: Чорноморський національний університет імені Петра Могили: вул. 68 десантників 10, Миколаїв, 54003, Україна.

Aleksandr Yevtushenko: Petro Mohyla Black Sea National University: 68 Desantnykiv str. 10, Mykolaiv, 54003, Ukraine.

\section{ORCID.ORG./ 0000-0002-5161-3312}

\section{E-mail: alnievt@ukr.net}

Суслов Микола Миколайович: Чорноморський національний університет ім. Петра Могили: вул. 68 десантників 10, Миколаїв, 54003, Україна.

Mykola Suslov: Petro Mohyla Black Sea National University: 68 Desantnykiv str. 10, Mykolaiv, 54003, Ukraine.

ORCID.ORG./ 0000-0003-0595-237X 


\section{E-mail: Suslov20@ukr.net}

Верба Світлана Миколаївна: Чорноморський національний університет ім. Петра Могили: вул. 68 десантників 10, Миколаїв, 54003, Україна.

Svitlana Verba: Petro Mohyla Black Sea National University: 68 Desantnykiv str. 10, Mykolaiv, 54003, Ukraine.

ORCID. ORG./ 0000-0002-6156-1384

E-mail: mag_idu@ukr.net 